\title{
Protective effects of ascorbic acid against the genetic and epigenetic alterations induced by 3,5-dimethylaminophenol in AA8 cells
}

\author{
Ming-Wei Chao ${ }^{a, b *}{ }^{\dagger}$, Pınar Erkekoglu ${ }^{b, c t}$, Chia-Yi Tseng ${ }^{d}$, Wenjie Ye ${ }^{b}$, \\ Laura J. Trudel $^{\text {b }}$, Paul L. Skipper ${ }^{\text {b }}$, Steven R. Tannenbaum ${ }^{\text {b }}$ \\ and Gerald N. Wogan
}

\begin{abstract}
Exposure to monocyclic aromatic alkylanilines (MAAs), namely 2,6-dimethylaniline (2,6-DMA), 3,5-dimethylaniline (3,5-DMA) and 3-ethylaniline (3-EA), was significantly and independently associated with bladder cancer incidence. 3,5-DMAP (3,5-dimethylaminophenol), a metabolite of 3,5-DMA, was shown to induce an imbalance in cytotoxicity cellular antioxidant/ oxidant status, and DNA damage in mammalian cell lines. This study was designed to evaluate the protective effect of ascorbic acid (Asc) against the cytotoxicity, reactive oxygen species (ROS) production, genotoxicity and epigenetic changes induced by 3,5-DMAP in AA8 Chinese Hamster Ovary (CHO) cells. In different cellular fractions, 3,5-DMAP caused alterations in the enzyme activities orchestrating a cellular antioxidant balance, decreases in reduced glutathione levels and a cellular redox ratio as well as increases in lipid peroxidation and protein oxidation. We also suggest that the cellular stress caused by this particular alkylaniline leads to both genetic (Aprt mutagenesis) and epigenetic changes in histones 3 and 4 (H3 and H4). This may further cause molecular events triggering different pathological conditions and eventually cancer. In both cytoplasm and nucleus, Asc provided increases in 3,5-DMAP-reduced glutathione levels and cellular redox ratio and decreases in the lipid peroxidation and protein oxidation. Asc was also found to be protective against the genotoxic and epigenetic effects initiated by 3,5-DMAP. In addition, Asc supplied protection against the cell cycle (G1 phase) arrest induced by this particular alkylaniline metabolite. Copyright $\odot 2014$ John Wiley \& Sons, Ltd.
\end{abstract}

Keywords: alkylaniline; monocyclic aromatic amine; 3,5-dimethylaminophenol; ascorbic acid; genotoxicity; cytotoxicity; reactive oxygen species

\section{Introduction}

Cigarette smoking and high exposure to permanent hair dyes are established risk factors for bladder cancer (Castelao et al., 2001). Alkylamines are present in tobacco smoke and hair dyes. They are the leading putative factors responsible for bladder cancer development in smokers and among people who are highly exposed to these dyes (Gago-Dominguez et al., 2001; Gago-Dominguez et al., 2003). The results of a non-occupational epidemiologic study, in which exposure to alkylanilines was determined through hemoglobin adduct assays, showed that three of these compounds, namely 2,6-dimethylaniline (2,6-DMA), 3, 5-dimethylaniline (3,5-DMA) and 3-ethylaniline (3-EA), were significantly and independently associated with bladder cancer incidence in Los Angeles County (Gan et al., 2004).

2,6- and 3,5-DMA are alkylanilines mostly used in the dye industry. They are also the metabolites of some drugs (e.g. lidocaine and xylazine) and pesticides (e.g. metalaxyl), and it is an impurity in technical grade metalaxyl (Bryant et al., 1988; Headley et al., 1996). 2,6-DMA-hemoglobin adduct levels were significantly higher in patients receiving lidocaine for local anesthesia or cardiac arrhythmias vs. a control (Bryant et al., 1994). However, the presence of 2,6-DMA-hemoglobin adducts in humans not exposed to lidocaine suggests that exposure to 2,6-DMA can also be attributed to other sources (Bryant et al., 1988).
3,5-DMA is a known nasal carcinogen in rats (1993). Besides, it was shown to cause cancers of the bladder, liver and subcutaneous tissue of mice. Its primary metabolite is 3,5-dimethylaminophenol (3,5-DMAP) (Chao et al., 2012). This metabolite is suggested to be potentially genotoxic by a mechanism involving non-enzymatic oxidation to the iminoquinone and quinone, which are strongly electrophilic species (Chao et al., 2012; Hill et al., 1994). Furthermore, Chao et al. (2012) has shown that 3,5-DMAP was able to cause cytotoxicity via generation of $\mathrm{H}_{2} \mathrm{O}_{2}$ and the hydroxyl ( $(\mathrm{OH})$

*Correspondence to: Ming-Wei Chao, Department of BioScience Technology, Chung Yuan Christian University, Chungli, Taoyuan, Taiwan 320.

Email: chao@cycu.edu.tw

\footnotetext{
+ Both authors contributed equally to this work.
}

${ }^{a}$ Department of BioScience Technology, Chung Yuan Christian University, Chungli, Taoyuan, Taiwan 320

${ }^{b}$ Department of Biological Engineering, Massachusetts Institute of Technology, Cambridge, MA, 02139, USA

'Hacettepe University, Faculty of Pharmacy, Department of Toxicology, 06100 Ankara, Turkey

${ }^{d}$ Department of Biomedical Engineering, Chung Yuan Christian University, Chungli, Taoyuan, Taiwan 320 
radical in Chinese Hamster Ovary $(\mathrm{CHO})$ cells. Besides, it caused upregulation of procaspase 3 , which further points out the induction of apoptosis (Chao et al., 2012; Hill et al., 1994). 3,5-DMA was also suggested to be involved in human carcinogenesis owing to the results of toxicologic studies (Bryant et al., 1988).

Several potentially damaging species (often termed reactive oxygen and nitrogen species, ROS/RNS) arise as by-products of normal metabolism and from exposure to environmental chemicals (Evans \& Halliwell, 2001). The function of an antioxidant is to protect the cells from the damage caused by free radicals (Halliwell, 2011). If not counteracted by antioxidants, oxidative stress might cause acute damage to important biomolecules including cellular proteins, lipids and DNA (Kern \& Kehrer, 2005; Martindale \& Holbrook, 2002). Accumulating data has implicated that low antioxidant levels may contribute to the risk of several types of malignancies, including bladder cancer (Baliga et al., 2007; Peters \& Takata, 2008). Currently, there is considerable interest in using different antioxidant molecules that might prevent cytotoxicity, genotoxicity and cancer. Using antioxidants against the toxic effects of alkylanilines and their metabolites (particularly 3,5-DMAP) has been a research topic for our group in past years. Recently, we have shown that $\mathrm{N}$-acetylcysteine (NAC) and selenocompounds can protect AS52 cells from the oxidative damage caused by 3,5-DMAP (Chao et al., 2014; Erkekoglu et al., 2014). Ascorbic acid (Asc) is a water soluble dietary antioxidant. ${ }^{\circ} \mathrm{OH}$ is formed from $\mathrm{H}_{2} \mathrm{O}_{2}$ and it is the most detrimental reactive oxygen species (ROS), owing to its high interaction with nucleic acids, proteins and lipids. Asc can terminate these chain radical reactions by transferring a single electron, owing to the stability of its own radical ion called 'semidehydroascorbate' (Blokhina et al., 2003; Choe \& Min, 2006). Thus, Asc is able to suppress ROS efficiently by reducing DNA damage (Crott \& Fenech, 1999). In addition, Asc also acts with vitamin $\mathrm{E}$, to quench free radicals and prevent lipid peroxidation and protein oxidation (Niki et al., 1995).

Apropos to this knowledge and information, this study was designed to investigate the protective effects of Asc on cytotoxicity, oxidant/antioxidant parameters, cell cyle arrest, mutation frequency and epigenetic changes caused by 3,5-DMAP in CHO AA8 cells.

\section{Materials and Methods}

\section{Chemicals and Reagents}

All chemicals including Asc, triethanolamine and vinylpyridine were purchased from Sigma-Aldrich (St. Louis, MO, USA). Propidium iodide (PI), RNase A and protease inhibitor cocktail were also from Sigma-Aldrich. All cell culture reagents were purchased from Lonza (Walkersville, MD, USA). Fetal bovine serum (FBS) was obtained from Atlanta Biologicals (Lawrenceville, GA, USA).

\section{Kits}

Nuclear and Cytoplasmic Extraction kits (NE-PER) was purchased from Thermo Scientific (Rockford, IL, USA). The cell proliferation reagent 4-[3-(4-iodophenyl)-2-(4-nitro-phenyl)-2H-5-tetrazolio]-1, 3-benzene disulfonate] (WST-1) kit was purchased from Roche Applied Science (Indianapolis, IN, USA). The 5-(and 6-) chloromethyl2',7'-dichlorodihydrofluorescein diacetate (CM- $\left.\mathrm{H}_{2} \mathrm{DCFA}\right)$ ROS detection kit was from Molecular Probes/Invitrogen (Eugene, OR, USA). Bicinchoninic acid (BCA), glutathione peroxidase (GPX1), thioredoxin reductase (TrxR), catalase (CAT), superoxide dismutase (SOD), glutathione reductase (GR), glutathione S-transferase (GST) and total glutathione (total GSH) kits were from Sigma-Aldrich. The thiobarbituric acid reactive substance (TBARS) kit and carbonyl assay kit were from Cayman Chemical Company (Ann Arbor, Ml, USA). Histone $3(\mathrm{H} 3)$ and histone $4(\mathrm{H} 4)$ acetylation ELISA kits and histone acetylase (HAT) and histone deacetylase (HDAC) ELISA kits were from Epigentek (Brooklyn, NY, USA).

\section{Cell Culture and Treatment}

The $\mathrm{CHO}$ AA8 cells were obtained from the American Type Culture Collection (ATCC) (Rockville, MD, USA). They were grown in Ham's medium supplemented with $100 \mathrm{U} \mathrm{ml}^{-1}$ penicillin, $100 \mu \mathrm{g} \mathrm{ml}^{-1}$ streptomycin and $10 \%$ FBS in a humidified atmosphere with $5 \% \mathrm{CO}_{2}$ at $37^{\circ} \mathrm{C}$. Cells were subcultured when confluency reached to $90 \%$.

\section{Experimental Groups}

In the present study, $\mathrm{CHO}$ AA8 cells were chosen according to the results of our previous experiments which showed that these cells were susceptible to the toxic effects of 3,5-DMAP at relatively low doses compared with human primary bladder cell lines (Chao et al., 2012, 2014).

AA8 cells ( 1000000 per dish) were plated at six-well plate 1 day prior to the experiments. The experimental groups were:

(1) Control Group (C): Control AA8 cells.

(2) Asc-treated Group (Asc): AA8 cells pre-treated with Asc $\left(50 \mathrm{mg} \mathrm{ml}^{-1}\right)$ for $24 \mathrm{~h}$.

(3) 3,5-DMAP Group (D25): AA8 cells were treated with $25 \mu \mathrm{M}$ 3,5-DMAP (in serum-free medium) for $1 \mathrm{~h}$.

(4) Asc- and 3,5-DMAP Group (D25-Asc): AA8 cells were pretreated with Asc for $24 \mathrm{~h}$; later treated with $25 \mu \mathrm{M}$ 3,5-DMAP (in serum free medium) for 1 h. 3,5-DMAP was synthesized in our lab according to Chao et al. (2012). For the 3,5-DMAP treated groups, after treatment with the chemical for $1 \mathrm{~h}$, cells were washed twice with fresh serum-free medium and the cells were incubated in regular fresh medium for a further $24 \mathrm{~h}$ at $37{ }^{\circ} \mathrm{C}$. For the Asc/D group, cells were incubated in fresh serum-free media with Asc for an additional $24 \mathrm{~h}$ at $37^{\circ} \mathrm{C}$.

\section{Preparation of Nuclear and Cytoplasmic Extracts}

Cell suspensions were harvested by centrifuging at $500 \mathrm{~g}$ for $5 \mathrm{~min}$. Cells were then washed by suspending the cell pellet with phosphate-buffered saline (PBS) and centrifugated at $500 \mathrm{~g}$ for $3 \mathrm{~min}$. After discarding the supernatant, nuclear and cytoplasmic extracts were prepared using the dry pellet by a nuclear and cytoplasmic extraction kit in the presence of a protease inhibitor cocktail.

\section{Determination of Cytotoxicity}

The cytotoxicity assay was performed using a WST-1 kit. The kit measures mitochondrial enzyme activity via conversion of WST-1 to formazan. After treatment, cells were washed with PBS and suspended in $1 \mathrm{ml}$ of fresh medium. Cells $(10 \mu \mathrm{l})$ were then pipetted into a 96-well plate. A mixture of water-soluble kit reagent $(10 \mu \mathrm{l})$ plus fresh medium $(90 \mu \mathrm{l})$ was added to each well. The plate was incubated at $37{ }^{\circ} \mathrm{C}$ for $1 \mathrm{~h}$ in the dark. A 
microquant micro-reader (Biotek Instruments Inc, Winooski, VT, USA) was used to test the absorbance of the produced formazan at $495 \mathrm{~nm}$. The values were normalized and presented as the percentage difference of negative controls.

\section{Quantification of Intracellular ROS Production}

Intracellular ROS detection studies were performed using a 'Reactive Oxygen Species Detection kit (CM- $\mathrm{H}_{2}$ DCFA ROS detection kit)'. The method involved the analysis of the accumulation of ROS generation and is based on the conversion of the non-fluorescent probe $\mathrm{CM}-\mathrm{H}_{2} \mathrm{DCFDA}$ to green-fluorescent CM-DCF. After the treatments, the cells were washed with PBS and suspended in $1 \mathrm{ml}$ per well serum-free medium. Cell suspension solutions ( $100 \mu \mathrm{l})$ of each dose were pipetted into 96-well plates and mixed with Hank's Buffered Salt Solution (HBSS, $10 \mu \mathrm{l}$ ) containing $\mathrm{CM}-\mathrm{H}_{2}$ DCFDA (final concentration in each well was $25 \mu \mathrm{M}$ ) which was activated by preincubation at $37{ }^{\circ} \mathrm{C}$ for $30 \mathrm{~min}$. ROS generation was detected immediately using the HTS 7000 Plus Bio Assay micro-reader (PerkinElmer Life Sciences, Waltham, MA, USA) at an excitation wavelength of $485 \mathrm{~nm}$, and emission wavelength of $530 \mathrm{~nm}$. The level of ROS production was normalized to the negative controls and cell viability, and it was presented as a percentage of the control.

\section{Analysis of Exogenous ROS Production in a Cell-Free Model}

Analysis of exogenous ROS production in a cell-free model was also performed using the same 'Reactive Oxygen Species Detection kit'. Previously, Ye et al. (2012) has shown that 3,5-DMAP anchored onto histone lysines (Lys) (Crott \& Fenech, 1999; Ye et al., 2012). Therefore, it is reasonable to assess whether Lys bound 3,5-DMAP induces ROS generation in a cell-free condition. $\mathrm{CM}-\mathrm{H}_{2}$ DCFDA ( $10 \mu \mathrm{l}, 25 \mu \mathrm{M}$ as a final concentration) was incubated at $37{ }^{\circ} \mathrm{C}$ for 30 min prior to adding DMAP (at both 25 and $50 \mu \mathrm{M}) \pm$ Asc to the serum-free culture media. Lys-3, 5-DMAP was synthesized with our previous method (Crott \& Fenech, 1999). The fluorescence was read on a HTS 7000 Plus Bio-assay Reader (495 nm excitation; PerkinElmer Life Sciences) at an excitation wavelength of $485 \mathrm{~nm}$ and emission wavelength of $530 \mathrm{~nm}$. The relative fluorescence unit (RF) values were normalized to the blank and presented as the level of exogenous ROS generation.

\section{Determination of Antioxidant Enzyme Activities}

Throughout the spectrophotometric and spectrofluorometric measurements, SpectraMax M2 (Molecular Devices, Sunnyvale, CA, USA) was used as a spectrophotometer and spectrofluorometer. SoftMax Pro software (Molecular Devices) was used for quantification.

The activity of GPx1 was measured in a coupled reaction with glutathione reductase (GR) as described earlier using a 'glutathione peroxidase assay kit' (Sigma-Aldrich). The assay is based on the instant and continuous reduction of oxidized glutathione (GSSG) formed during a GPx1 reaction by an excess of GR activity providing for a constant level of GSH with the same endpoints mentioned by Flohe and Gunzler (1984). As a substrate, t-butyl hydroperoxide was used and the concomitant oxidation of NADPH was monitored spectrophotometrically at $340 \mathrm{~nm}$. One unit of enzyme was defined as the amount of GPx 1 that transforms $1 \mu \mathrm{mol}$ of NADPH to NADP per min at $37^{\circ} \mathrm{C}$.
TrxR activity was determined using a 'thioredoxin reductase commercial assay' at $412 \mathrm{~nm}$ with the same endpoints mentioned previously (Arner, 1999; Arner et al., 1999). One unit of TrxR activity was defined as the amount of enzyme that caused an increase in absorbance of 1.0 per min and per $\mathrm{ml}$ at $\mathrm{pH} 7.0$ at $25^{\circ} \mathrm{C}$.

CAT activity was determined colorimetrically using a 'catalase commercial assay' by measuring the enzymatic decomposition of $\mathrm{H}_{2} \mathrm{O}_{2}$ at $520 \mathrm{~nm}$. One unit of CAT was defined as the enzyme that decomposed $1 \mu \mathrm{M} \mathrm{H}_{2} \mathrm{O}_{2}$ to oxygen and water per minute at $\mathrm{pH} 7.0$ at $25^{\circ} \mathrm{C}$.

The total SOD activity was measured by a 'total SOD activity commercial kit' colorimetrically. The activity was determined using WST-1 that produces a water-soluble formazan dye upon reduction with a superoxide $\left(\mathrm{O}_{2}{ }^{-}\right)$anion. The rate of the reduction with $\mathrm{O}_{2}$ was linearly related to the xanthine oxidase $(\mathrm{XO})$ activity and was inhibited by SOD. The $\mathrm{IC}_{50}(50 \%$ inhibition activity of SOD) was determined by this colorimetric method. As the absorbance at $440 \mathrm{~nm}$ was proportional to the amount of $\left(\mathrm{O}_{2}{ }^{-}\right)$anion, the inhibition of SOD activity as an inhibition activity was quantified by measuring the decrease in the color development at $440 \mathrm{~nm}$.

The activity of GR was measured by a 'glutathione reductase commercial assay" (Sigma-Aldrich), based on the reduction of GSSG by NADPH in the presence of GR at $412 \mathrm{~nm}$. One unit of enzyme was defined as the enzyme activity that caused the reduction of $1 \mu \mathrm{mol}$ DTNB at $25^{\circ} \mathrm{C}$ at $\mathrm{pH} 7.5$.

GST activity was determined using a 'glutathione S-transferase assay kit' using 1-chloro-2,4 dinitrobenzene (CDNB) as a substrate at $340 \mathrm{~nm}$ and the enzyme activity was expressed in nmol per mg protein per min.

\section{Determination of Total, Reduced and Oxidized Glutathione Levels}

The total GSH content of the cell extracts was assessed using a 'total glutathione assay kit' at $412 \mathrm{~nm}$. For GSSG determination, reduced GSH was inactivated by the addition of 2-vinylpyridine in the presence of triethanolamine. The GSH content was calculated using the equation of GSH $=$ (Total GSH $-2 \times$ GSSG).

\section{Determination of Lipid Peroxidation}

Lipid peroxidation (LP) in nuclear and cytoplasmic extracts was quantified by measuring the concentration of TBARS by a spectrofluorometric assay using a 'TBARS assay kit' at an exitation wavelength of $532 \mathrm{~nm}$ and emission wavelength of $553 \mathrm{~nm}$ with the same endpoints by Richard et al. (1992). Quantification was achieved by parallel measurements of a standard curve of known TBARS concentrations, and the results were expressed as $\mathrm{nmol} \mathrm{g}^{-1}$ protein.

\section{Determination of Protein Oxidation}

The carbonyl groups as the biomarker of protein oxidation were determined using a 2,4-dinitrophenylhydrazine (DPNH) reaction and the amount of protein-hydrazone produced was quantified spectrophotmetrically at $360 \mathrm{~nm}$ using a 'carbonyl assay kit'. 


\section{Protein Determination}

The protein content of the samples was determined by BCA using a 'protein assay kit' according to the method of Krieg et al. (2005).

\section{Determination of Mutation Frequency}

The mutagenicity was assessed by determination of the induced mutation fraction in the aprt gene of AA8 cells. Cell aliquots $\left(\sim 1 \times 10^{6}\right.$ cells $)$ were treated with $3,5-D M A P \pm$ Asc for $1 \mathrm{~h}$. Cells were then grown (without further treatment) for 7 days to permit phenotypic expression, and plated $\left(\sim 3 \times 10^{5}\right.$ cells $)$ at $100-\mathrm{mm}$ dishes in 10 replicates in selective media containing 8 -azaadenine $\left(80 \mu \mathrm{g} \mathrm{ml}^{-1}\right)$ for 8 to 10 days to identify aprt mutants. To determine plating efficiency, 1500 cells from each dose in non-selective medium $(50 \mathrm{ml})$ were seeded in $100-\mathrm{mm}$ dishes $(\sim 300$ cells per $10 \mathrm{ml})$. After 8 days incubation, colonies were counted and mutant fraction was calculated according to a previous method (Wu et al., 2003). A similar process was used to estimate the background mutation rate in negative control cells (treated with $0.1 \%$ DMSO).

\section{Determination of Histone 3 and Histone 4 Acetylation and the Activity of Histone Acetylase and Histone Deacetylase}

$\mathrm{H} 3$ and $\mathrm{H} 4$ acetylations were evaluated using commercially available $\mathrm{H} 3$ and $\mathrm{H} 4$ acetylation ELISA Kits, according to the manufacturer's instructions. Briefly, AA8 cells $\left(5 \times 10^{6}\right.$ cells per well) were seeded on triplicate six-well plates and cells were exposed to 0 and $25 \mu \mathrm{M}$ of 3,5-DMAP \pm Asc for $1 \mathrm{~h}$ and then incubated for additional $24 \mathrm{~h}$. Later, cells were lysed and the histone proteins were extracted. Next, $5 \mu \mathrm{g}$ histone was added to the wells, which were pre-coated with acetylated-H3 and acetylated-H4 'capture' antibodies. The plates were then incubated, and washed. A biotin-conjugated 'detecting' primary antibody against either acetylated-H3 or acetylated-H4 was added and the plates were incubated for $1 \mathrm{~h}$ at room temperature. Later, the substrate solution was added, the plates were incubated for another 2-15 min at room temperature and absorbance was determined at $450 \mathrm{~nm}$. The levels of acetylated-H3 and acetylated-H4 were determined by comparison to a standard curve and normalized to the untreated controls. The acetylation levels were presented as the percentage of the control. The activity of HAT and HDAC were detected with commercially available HAT and HDAC ELISA kits. After the 3,5-DMAP treatment, the cells were collected and the nuclei were extracted in a nuclear lysis buffer. Nuclear extracts $(5 \mu \mathrm{g})$ were loaded into the pre-coated 96-well plate according to the manufacturer's instructions. Quantification was achieved by parallel measurements of a standard curve of known HAT and HDAC activities. The values were normalized by the untreated controls and presented as the percentage of the control.

\section{Determination of Cell Cycle Arrest}

The AA8 cells in exponential growth were treated with 3,5$\mathrm{DMAP} \pm \mathrm{Asc}$ at the indicated doses and the time. The cells were permeabilized in $100 \%$ cold ethanol at $-20{ }^{\circ} \mathrm{C}$ for 1 day and washed twice with cold $10 \%$ FBS and centrifuged at $500 \mathrm{~g}$ to remove debris. After the PBS wash, the cells and stained with propidium iodide $(\mathrm{PI})$ solution $\left(15 \mathrm{mg} \mathrm{m}^{-1} \mathrm{PI}\right.$ and $2.5 \mathrm{mg} \mathrm{ml}^{-1}$
RNase A). Stained cells were determined using FACScan flow cytometer (Becton Dickinson, CA, USA) and analyzed with using ModFit software (Becton Dickinson, CA, USA). The cell cycle phase level was presented as the percentage of total cell cycle phases (sub-G1+G1+S+G2/M).

\section{Statistical Analysis}

All the experiments were done at least in triplicate for all of the study groups. The results were expressed as mean \pm standard deviation (SD). The differences among the groups were evaluated with Kruskal-Wallis one-way analysis of variance, followed by Student's t-test using a Statistical Package for Social Sciences Program (SPSS) version 17.0 (SPSS Statistics for Windows, Chicago, IL, USA). $P$-values $<0.05$ were considered as statistically significant.

\section{Results}

\section{Ascorbic acid prevents 3,5-DMAP-induced ROS production and cytotoxicity}

The possible protective effects of Asc against the ROS-producing and cytotoxic effects of 3,5-DMAP were investigated by measuring intracellular ROS production and cell viability with two different protocols. In the first protocol, after cells were exposed to 3,5-DMAP $(5,10,25,50$ and $100 \mu \mathrm{M})$ for $1 \mathrm{~h}$, intracellular ROS production and cell survival were measured immediately. In the second protocol, after cells were exposed to 3,5-DMAP $(5,10,25,50$ and $100 \mu \mathrm{M})$ for $1 \mathrm{~h}$, cells were incubated for an additional $24 \mathrm{~h}$. As shown in Fig. 1, responses in the two treatments were similar. For the first protocol, ROS production (Fig. 1A) increased and cell viability (Fig. 1B) decreased in a dose-dependent manner in cells treated with 3,5-DMAP. Cell survival was the lowest and intracellular ROS production was the highest at $100 \mu \mathrm{M}$ concentration of 3,5-DMAP (20000\% increase in ROS and $90 \%$ decrease in cell survival). In the second protocol, after $24 \mathrm{~h}$ at $100 \mu \mathrm{M}$ concentration of 3,5-DMAP, 39000\% increase in ROS generation and $99 \%$ decrease in the cell survival were observed. No significant elevations in ROS generation or cytotoxicity were observed at doses below $25 \mu \mathrm{M}$ 3,5-DMAP in both of the treatment protocols. The concurrent application of 3,5-DMAP and Asc provided complete inhibition of ROS and cytotoxicity in both cell types except for the highest dose $(100 \mu \mathrm{M})$ of 3,5-DMAP.

\section{Antioxidant and Oxidant Parameters}

All the oxidant and antioxidant parameters were also detectable in the nucleus, however $\sim 3-10$-fold lower compared with cytoplasm.

\section{Antioxidant Enzymes}

Table 1 shows the cytopasmic and nuclear selenoenzyme activities in the study groups. The activity of nuclear GPx1 is $\sim 3$-fold lower than cytoplasmic GPx1 and the activity of nuclear TrxR is $\sim 10$-fold lower than cytoplasmic TrxR. The nuclear activities of CAT and GR were $~ 3$-fold, the nuclear activity of SOD was $\sim 2.5$-fold and the activity of GST was $\sim 7$-fold lower than that of cytoplasmic activities. 


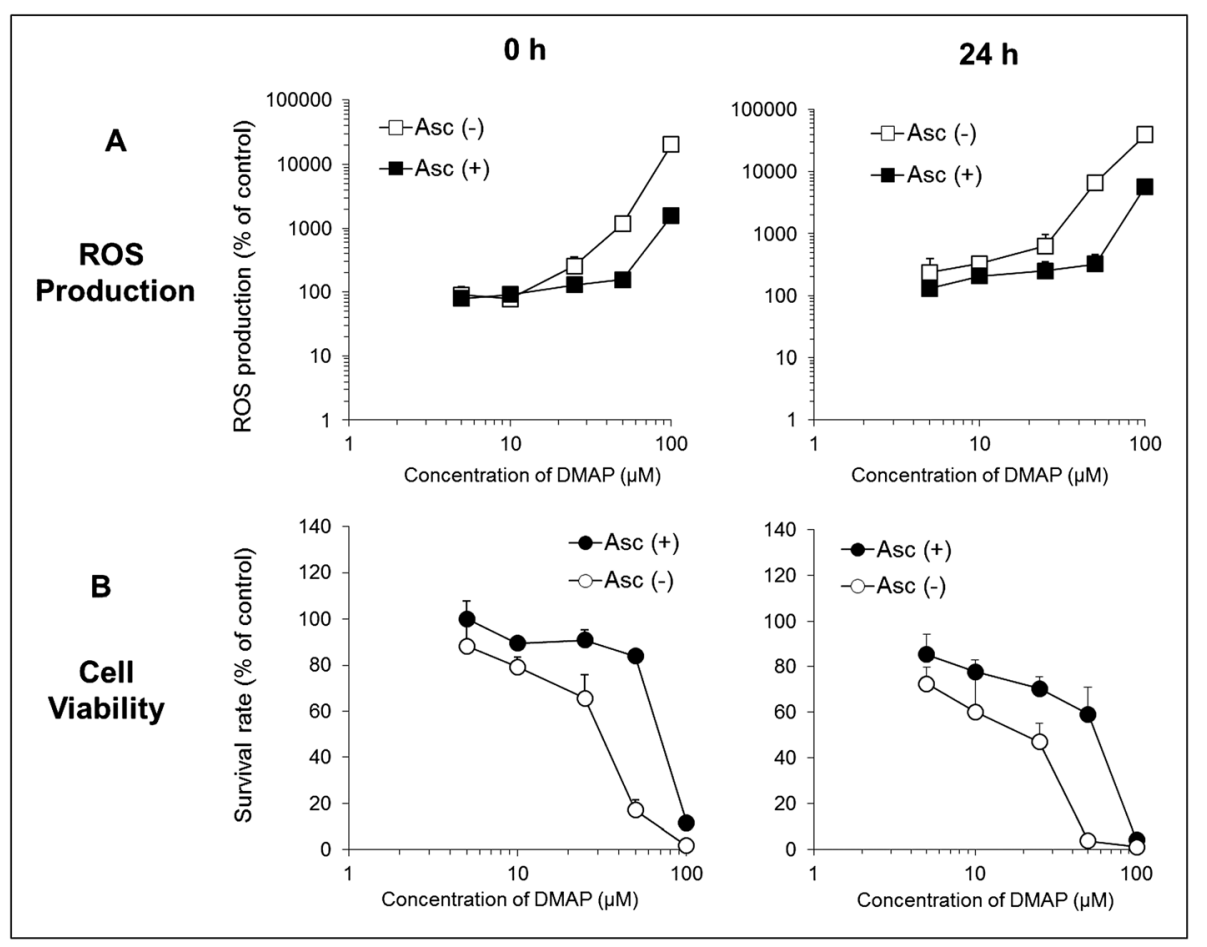

Figure 1. Quantification of intracellular reactive oxygen species (ROS) and cell viability. Both ROS production and cell viability in the study groups were expressed in \% of control. Cell killing and ROS generation caused by 3,5-DMAP is readily apparent in a dose-depend manner at both 0 and $24 \mathrm{~h}$ after treatment. Protection against these two damages by Asc is readily apparent. Values are given as mean \pm SD of $n=3$ independent experiments.

Table 1. Cytopasmic antioxidant enzyme activities in groups pretreated for $24 \mathrm{~h}$ with ascorbic acid, followed by 1-h treatment with 3,5-DMAP +/- ascorbic acid

\begin{tabular}{|c|c|c|c|c|c|c|}
\hline & $\begin{array}{c}\text { GPx1 } \\
\left(\mathrm{U} \mathrm{mg}^{-1}\right. \\
\text { protein) }\end{array}$ & $\begin{array}{c}\text { TrxR } \\
\left(\mathrm{mU} \mathrm{mg}^{-1}\right. \\
\text { protein) }\end{array}$ & $\begin{array}{c}\text { CAT } \\
\left(\mathrm{U} \mathrm{mg}^{-1}\right. \\
\text { protein) }\end{array}$ & $\begin{array}{c}\text { SOD } \\
\left(\mathrm{U} \mathrm{mg}^{-1}\right. \\
\text { protein })\end{array}$ & $\begin{array}{c}\mathrm{GR} \\
\left(\mathrm{mU} \mathrm{mg}^{-1}\right. \\
\text { protein) }\end{array}$ & $\begin{array}{c}\text { GST } \\
\left(\mathrm{nmol} \mathrm{mg}{ }^{-1}\right. \\
\text { protein per min) }\end{array}$ \\
\hline Control & $0.117 \pm 0.006^{\mathrm{a}}$ & $0.242 \pm 0.020^{a}$ & $0.271 \pm 0.010^{\mathrm{a}}$ & $18.238 \pm 0.110^{\mathrm{a}}$ & $0.110 \pm 0.006^{\mathrm{a}}$ & $0.029 \pm 0.004^{a, b}$ \\
\hline Asc & $0.153 \pm 0.015^{b}$ & $0.494 \pm 0.023^{b}$ & $0.271 \pm 0.012^{\mathrm{a}}$ & $19.874 \pm 2.370^{\mathrm{a}}$ & $0.111 \pm 0.009^{\mathrm{a}}$ & $0.030 \pm 0.001^{\mathrm{a}}$ \\
\hline D25 & $0.115 \pm 0.016^{a}$ & $0.135 \pm 0.005^{c}$ & $0.195 \pm 0.010^{b}$ & $27.822 \pm 0.505^{b}$ & $0.039 \pm 0.007^{b}$ & $0.022 \pm 0.002^{b}$ \\
\hline D25-Asc & $0.159 \pm 0.019^{b}$ & $0.466 \pm 0.002^{\mathrm{a}}$ & $0.279 \pm 0.007^{\mathrm{a}}$ & $20.900 \pm 0.384^{a}$ & $0.101 \pm 0.008^{a}$ & $0.030 \pm 0.002^{a, b}$ \\
\hline
\end{tabular}

GPx1, glutathione peroxidase 1; TrxR, thioredoxin reductase; CAT, catalase; SOD, total superoxide dismutase; GR, glutathione reductase; GST, glutathione S-transferase.

Values are given as mean \pm SD of $n=3$ experiments and duplicate measurements.

a b , CColumns that do not share the same letters are significantly different from each other $(P<0.05)$.

(1) Control Group (C): Control AA8 cells for 24-h groups; (2) Asc-treated Group (AA): AA8 cells pre-treated with Asc (50 mg ml ${ }^{-1}$ ) for 24 h; (4) 3,5-DMAP Group (D): AA8 cells were treated with $25 \mu \mathrm{M}$ 3,5-DMAP (in serum-free medium) for 1 h; (5) Asc- and 3,5-DMAP Group (AA/D): AA8 cells were pre-treated with Asc $\left(50 \mathrm{mg} \mathrm{ml}^{-1}\right)$ for $24 \mathrm{~h}$; later cells were treated with $25 \mu \mathrm{M} 3,5$-DMAP (in serumfree medium) for $1 \mathrm{~h}$.

For the 3,5-DMAP-treated groups, after treatment with the chemical for $1 \mathrm{~h}$, cells were washed twice with fresh serum-free medium and the cells were incubated in regular fresh medium for further $24 \mathrm{~h}$ at $37^{\circ} \mathrm{C}$ for groups. For AA/D group, cells were incubated in fresh serum-free media with Asc $\left(50 \mathrm{mg} \mathrm{ml}^{-1}\right)$ for further $24 \mathrm{~h}$ at $37^{\circ} \mathrm{C}$.

Tables 1 and 2 show the cytoplasmic and nuclear antioxidant enzyme activities of the study groups. Although we did not observe any significant change in cytoplasmic GPx1 activity after 3,5-DMAP exposure (Table 1), nuclear GPx1 activity showed marked decreases (20\%) after AA8 cells were treated with 3,5DMAP (Table 2) versus the control. Asc provided significant increases in both cytoplasmic (31\%) and nuclear (16\%) GPx1 activity compared with the control group. Besides, Asc with 3,5-DMAP supplied marked increases in both cytoplasmic (37\%) and nuclear (19\%) GPx1 activity compared with the 3,5DMAP group.

Both cytoplasmic (35\%) and nuclear (44\%) TrxR activities showed marked decreases with 3,5-DMAP treatment versus the control group (Tables 1 and 2). Asc supplementation provided 


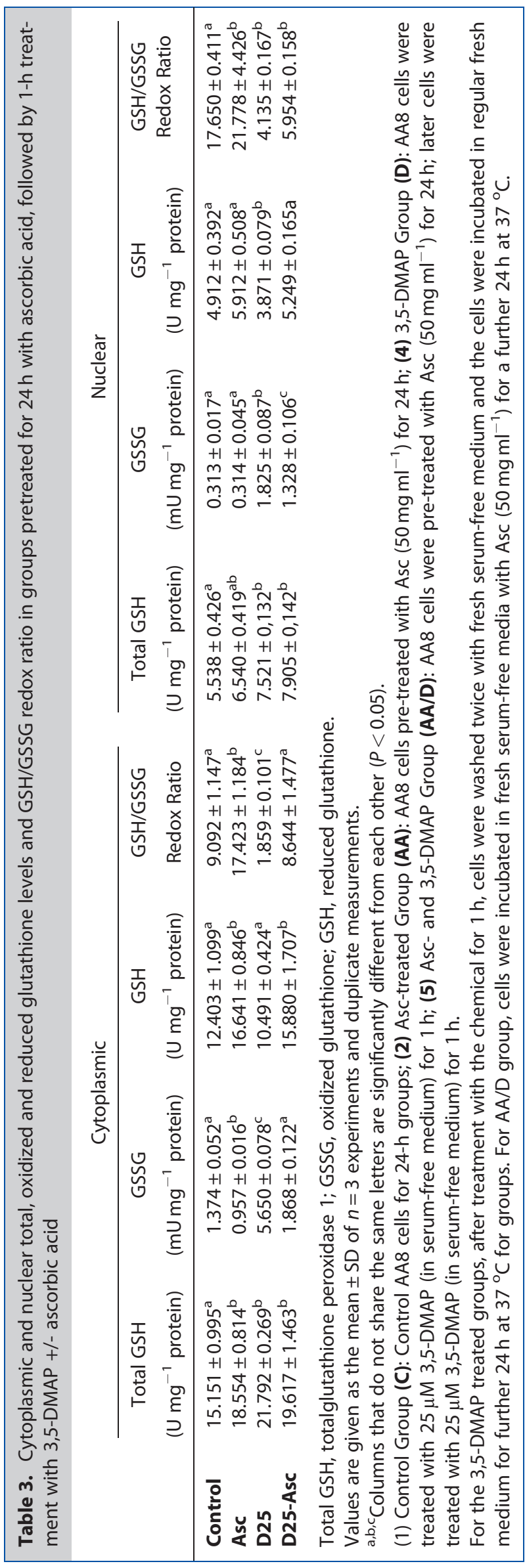

an increase in the mutation frequency versus the negative control, however, aprt mutations were not further induced by a higher dose $(50 \mu \mathrm{M})$ of 3,5-DMAP. The samples treated with Asc plus two different doses of 3,5-DMAP (25 and $50 \mu \mathrm{M})$, showed slight dose-dependent decreases in aprt mutagenesis, but with no significant difference was observed when compared with the control.

\section{3,5-DMAP Increases Histone 3 and Histone 4 Acetylation}

In our current work, we tried to explore whether 3,5-DMAP caused modifications in the Lys of $\mathrm{H} 3$ and $\mathrm{H} 4$, with altering the activity of acetylation enzymes HAT and HDAC. As shown in Fig. 3, H3 and H4 were hyperacetylized (126\% and 133\%, respectively vs. the control) by 3,5-DMAP treatment $(25 \mu \mathrm{M})$. These results implicate that 3,5-DMAP might bind onto the Lys of $\mathrm{H} 3$ and $\mathrm{H} 4$. In contrast, $\mathrm{H} 3$ and $\mathrm{H} 4$ acetylations were at control levels when 3,5-DMAP was applied with Asc. We observed marked enchancement in HAT activity and marked decreases in HDAC activity after 3,5-DMAP exposure versus the control. HAT and HDAC activities remained at control levels when 3,5-DMAP was applied with Asc.

\section{Lysine Bound 3,5-DMAP Generates Exogenous ROS in a Cell-Free System}

The exogenous ROS production produced by Lys-3,5-DMAP in the serum-free MEM medium is summarized in Fig. 4. As expected, the percentage of Relative Fluorescence Unit (RFU) after 25 and $50 \mu \mathrm{M}$ 3,5-DMAP applications caused increases in ROS levels up to $360 \%$ and $585 \%$ within $2 \mathrm{~h}$, respectively. The addition of Asc to the co-cultured system entirely blocked the free radicals produced at both of the 3-5-DMAP doses.

\section{Determination of Cell Cycle Arrest}

AS 3,5-DMAP was found to cause cytotoxicity and modification of histones, we examined whether this chemical could alter the ability of cells to progress through the cell cycle. In addition, determination of histone acetylation levels would also give the opportunity to evaluate the doubling of histone content based on DNA replication. To obtain the correlation between cell cycle progression and histone acetylation levels, it is necessary to identify cell cycle phases by observing the cellular distribution according to the DNA content (Ronzoni et al., 2005). While increasing 3,5-DMAP doses, the DNA content distribution (at $2 \mathrm{~N}$ ) decreased and this phenomenon indicated that 3,5-DMAP had an effect on cell-cycle progression (Fig. 5A). Furthermore, after 3,5-DMAP exposure, the percentage increase in the G1 phase raised from $42 \%$ to $72 \%$. The $S$ and $\mathrm{G} 2 / \mathrm{M}$ phase decreased from $40 \%$ to $23 \%$ and $16 \%$ and $3.7 \%$ at 10 and $25 \mu \mathrm{M}$ doses. These alterations revealed a G1 phase arrest after 3,5-DMAP treatment (Fig. 5B). In contrast, Asc mitigates the 3,5-DMAP induced effects and raises the $S$ and $\mathrm{G} 2 / \mathrm{M}$ ratio from $23 \%$ to $44 \%$ and $3.7 \%$ to $15 \%(P<0.01, n=3)$, respectively.

\section{Discussion}

The cellular production of ROS is a well-known physiological process. Several previous studies have provided evidence that free radical-induced oxidative damage of cell membranes, DNA and proteins might be the cause of several diseases, including cancer 
Table 4. Cytoplasmic and nuclear thiol groups, lipid peroxidation and protein oxidation levels in groups pretreated for $24 \mathrm{~h}$ with ascorbic acid, followed by 1 -h treatment with 3,5-DMAP +/- ascorbic acid

\begin{tabular}{|c|c|c|c|c|c|c|}
\hline & \multicolumn{3}{|c|}{ Cytoplasmic } & \multicolumn{3}{|c|}{ Nuclear } \\
\hline & $\begin{array}{c}\text { TBARS } \\
\left(\mu \text { mol g }^{-1}\right. \\
\text { protein) }\end{array}$ & $\begin{array}{l}\text { Carbonyl Groups } \\
\text { (nmol mg } \\
\text { protein) }\end{array}$ & $\begin{array}{l}\text { Thiol Groups } \\
\text { (nmol mg } \\
\text { protein) }\end{array}$ & $\begin{array}{c}\text { TBARS } \\
\left(\mu \mathrm{mol} \mathrm{g}^{-1}\right. \\
\text { protein) }\end{array}$ & $\begin{array}{l}\text { Carbonyl Groups } \\
\text { (nmol mg } \\
\text { protein) }\end{array}$ & $\begin{array}{l}\text { Thiol Groups } \\
\text { (nmol mg } \\
\text { protein) }\end{array}$ \\
\hline Control & $0.057 \pm 0.002^{\mathrm{a}}$ & $1.642 \pm 0.062^{a}$ & $146.677 \pm 2.802^{\mathrm{a}}$ & $0.015 \pm 0.001^{\mathrm{a}}$ & $1.647 \pm 0.329^{a}$ & $49.720 \pm 2.324^{a}$ \\
\hline Asc & $0.051 \pm 0.003^{\mathrm{a}}$ & $1.798 \pm 0.111^{\mathrm{a}}$ & $161.397 \pm 3.692^{\mathrm{a}}$ & $0.013 \pm 0.001^{\mathrm{a}}$ & $1.455 \pm 0.444^{a}$ & $52.358 \pm 2.162^{a}$ \\
\hline D25 & $0.235 \pm 0.005^{b}$ & $3.124 \pm 0.333^{b}$ & $139.200 \pm 5.988^{a}$ & $0.132 \pm 0.022^{b}$ & $2.351 \pm 0.299^{b}$ & $45.533 \pm 1.347^{a}$ \\
\hline D25-Asc & $0.055 \pm 0.007^{\mathrm{a}}$ & $1.711 \pm 0.344^{a}$ & $144.458 \pm 0.223^{\mathrm{a}}$ & $0.036 \pm 0.003^{c}$ & $1.710 \pm 0.134^{\mathrm{a}}$ & $50.984 \pm 2.447^{a}$ \\
\hline \multicolumn{7}{|c|}{$\begin{array}{l}\text { TBARS: thiobarbituric acid reactive substance. } \\
\text { Values are given as the mean } \pm \text { SD of } n=3 \text { experiments and duplicate measurements. } \\
\text { a,b,c Columns that do not share the same letters are significantly different from each other }(P<0.05) \text {. } \\
\text { (1) Control Group (C): Control AA8 cells for } 24 \text {-h groups; (2) Asc-treated Group (AA): AA8 cells pre-treated with Asc }\left(50 \mathrm{mg} \mathrm{ml}^{-1}\right) \text { for } \\
24 \mathrm{~h} \text {; (4) 3,5-DMAP Group (D): AA8 cells were treated with } 25 \mu \mathrm{M} \mathrm{3,5-DMAP} \mathrm{(in} \mathrm{serum-free} \mathrm{medium)} \mathrm{for} 1 \mathrm{~h} \text {; (5) Asc- and 3,5-DMAP } \\
\text { Group (AA/D): AA8 cells were pre-treated with Asc }\left(50 \mathrm{mg} \mathrm{ml}^{-1}\right) \text { for } 24 \mathrm{~h} \text {; later cells were treated with } 25 \mu \mathrm{M} 3,5 \text {-DMAP (in serum- } \\
\text { free medium) for } 1 \mathrm{~h} \text {. } \\
\text { For the 3,5-DMAP treated groups, after treatment with the chemical for } 1 \mathrm{~h} \text {, cells were washed twice with fresh serum-free medium } \\
\text { and the cells were incubated in regular fresh medium for further } 24 \mathrm{~h} \text { at } 37^{\circ} \mathrm{C} \text { for groups. For AA/D group, cells were incubated in } \\
\text { fresh serum-free media with Asc }\left(50 \mathrm{mg} \mathrm{ml}^{-1}\right) \text { for a further } 24 \mathrm{~h} \text { at } 37^{\circ} \mathrm{C} \text { ). }\end{array}$} \\
\hline
\end{tabular}

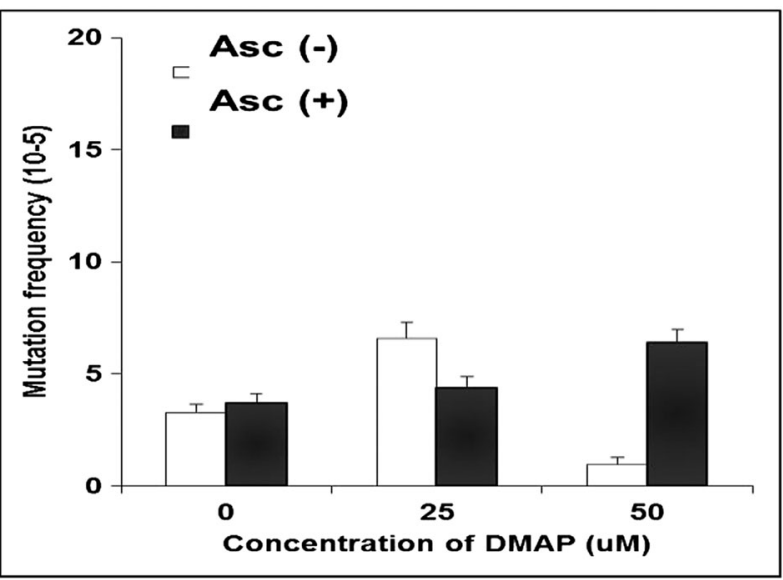

Figure 2. Mutation frequency in 3,5-DMAP with or without ascorbic acid-treated cells. In the absence of Asc AA8 cells are vulnerable to mutagenicity at 0,25 and $50 \mu \mathrm{M}$ 3,5-DMAP. Protection against mutagenicity is apparent when cells were grown with Asc. Values are given as mean \pm SD of $n=3$ independent experiments.

(Barnham et al., 2004). Bladder cancer is the nineth most common cancer in both sexes and the fourth most common cancer diagnosed in men. Men are about 3 to 4 times more likely to get bladder cancer during their lifetime than women. Oxidative stress may be involved in the emergence of this particular type of cancer (Reszka, 2012; Wu et al., 2010). Besides, smoking, occupational exposure to monocyclic aromatic amines (MAAs), particularly to alkylanilines and genetics, are suggested to be the other risk factors (Skipper et al., 2010).

Intrinsic antioxidant systems, such as enzymatic antioxidants and dietary antioxidants, provide an extensive array of protection that counteract potentially injurious oxidizing agents (Ames et al., 1999; Halliwell \& Cross, 1994). Asc is a soluble dietary antioxidant that plays an important role in controlling oxidative stress. About $90 \%$ of Asc in the average diet comes from fruits and vegetables (Vallejo et al., 2002). The protection provided by Asc against the cytotoxic and genotoxic effects of several environmental chemicals in vitro has been demonstrated before and is possibly as a result of its effect on the cellular redox equilibrium (Erkekoglu \& Baydar, 2010). This vitamin reacts directly with $\mathrm{O}_{2}{ }^{-},{ }^{\circ} \mathrm{OH}$ and singlet oxygen $\left({ }^{1} \mathrm{O}_{2}\right)$, which may be involved in both cancer initiation and tumor promotion (Bendich \& Langseth, 1995).

Alkylanilines are a class of chemicals that may affect human health without having a well-clarified genotoxicity mechanism (Skipper et al., 2010). 3,5-DMA is classified as a possible carcinogenic to humans (Category IIB) by the International Agency for Research on Cancer (IARC) (IARC monographs). Our recent findings as well as the results of the current study also suggest that 3,5-DMAP, the metabolite of 3,5-DMA, can cause cytotoxicity in a dose-dependent manner, possibly owing to its ability to generate oxidative stress. Furthermore, high ROS production could also be one of the underlying factors of the mutagenic and genotoxic potentials of 3,5-DMAP in AA8 cells (Chao et al., 2012; Ye et al., 2012). Ye et al. (2012) has also suggested that 3,5-DMAP can redox the cycle through the corresponding quinone imines to generate ROS. The electrophilic quinoneimine intermediate, 3,5-DMQI, can react with protein thiols as a mechanism of immobilization in vivo. Recently, this phemenon was shown to be inhibited with the addition of NAC to As52 cell co-cultures (Chao et al., 2014). In the present study, we propose a mechanism for the toxicity of 3,5-DMAP in AA8 cells. This mechanism involves both high intracellular ROS generation and cytotoxicity. In addition, we suggest that at physiologically relevant concentrations $\left(50 \mathrm{mg} \mathrm{ml}^{-1}\right)$, Asc was shown to be protective against the 3,5DMAP-induced ROS production, cytotoxicity and mutagenesis. Previously, our group has shown that 2,6-DMA and its metabolites caused dose-dependent decreases in cell survival with very different potencies: 3,5-DMAP had the highest potency where $\mathrm{N}$-hydroxy dimethylaminophenol (N-OH-DMA) was intermediate; and 3,5-DMAP had the lowest (Chao et al., 2012). 


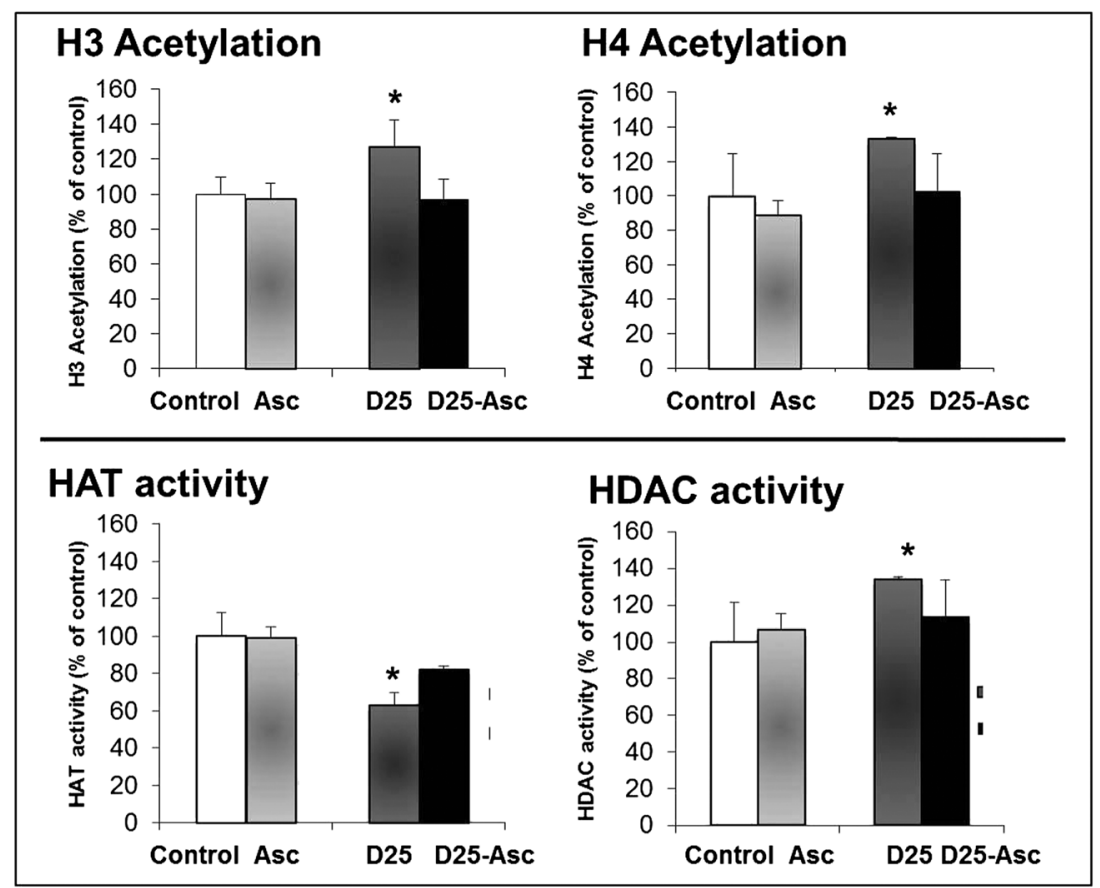

Figure 3. Histone modification in response to 3,5-DMAP \pm Asc. 3,5-DMAP $(25 \mu \mathrm{M})$ increases both $\mathrm{H} 3$ and $\mathrm{H} 4$ acetylation. The activity of HAT decreased and HDAC activity is increased in response to 3,5-DMAP. Protection against $\mathrm{H} 3$ and $\mathrm{H} 4$ hyperacetylation was apparent when cells were cultured with Asc. Values are given as mean \pm SD of $n=3$ independent experiments. ${ }^{*} P<0.05$ was considered statistically significant.

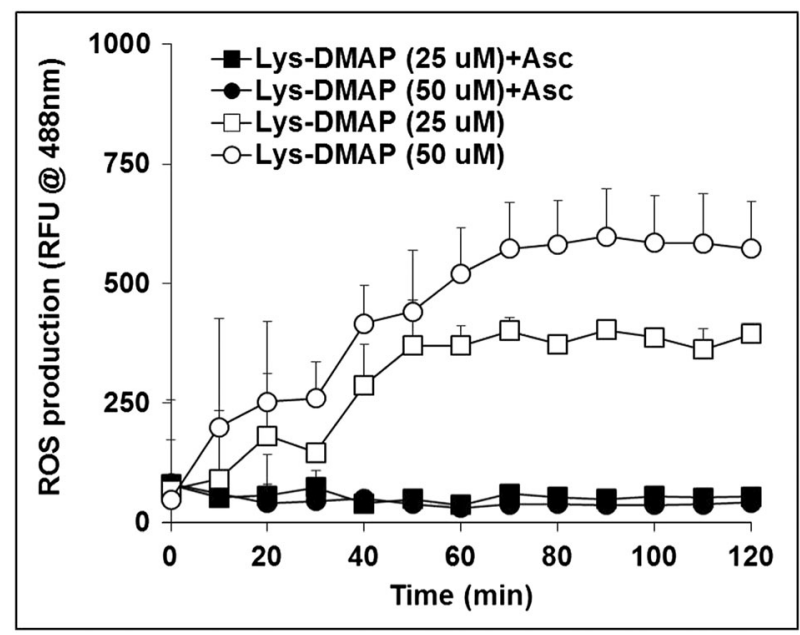

Figure 4. Lys-3,5-DMAP-induced reactive oxygen species (ROS) production in the cell-free media. The free radicals was produced with 25 and $50 \mu \mathrm{M}$ lys-3,5-DMAP \pm Asc and measured every $10 \mathrm{~min}$ within $2 \mathrm{~h}$. These data are presented as the RFU value minus blank. Each point is the mean \pm SD of three independent experiments.

In the present study, 3,5-DMAP exposure caused substantial changes in cellular antioxidant/oxidant parameters, and this phenomenon is the predominant evidence of a shift in the redox equilibrium towards oxidation. After $24 \mathrm{~h}$ of supplementation, Asc provided remarkable changes in the antioxidant/oxidant status of the 3,5-DMAP-treated cells. Concerning selenoenzymes, nuclear GPx1 activity and both cytoplasmic and nuclear TrxR activities showed marked decreases after AA8 cells were treated with 3,5-DMAP versus the control. In contrast, both CAT and GR activities in both of the cell fractions showed significant decreases and Asc provided significant increases in both cytoplasmic and nuclear activities of the four enzymes (namely GPx1, TrxR, CAT and GR) in comparison with the control group. However, SOD activity markedly increased in both of the cell fractions, possibly owing to a cellular adaptive responsive. Besides, these alterations might also occur to compensate for the high $\mathrm{O}_{2}^{-}$produced by 3,5-DMAP.

Cellular thiols play important roles in maintaining the cellular redox status (Dickinson \& Forman, 2002). GSH is the most important and abundant thiol in living organisms. The increases observed in total GSH levels in AA8 cells might be an adaptive response towards an oxidative insult. The elevation in GSSG levels indicates the ability of 3,5-DMAP to interfere with GSH and cause its oxidation. Moreoover, the redox ratio in both the cytoplasm and nucleus decreased dramatically with 3,5-DMAP treatment. Asc with 3,5-DMAP exposure provided significant increases in the redox ratio in the cytoplasm (365\%) and nucleus (44\%) versus 3,5-DMAP treatment. Previously, we have also observed that both NAC and selenium supplementations with 3,5-DMAP to AS52 cells provided substantial increases in the cellular redox ratio when applied compared with 3,5-DMAP treatment (Chao et al., 2014; Erkekoglu et al., 2014).

Lipid peroxidation and protein oxidation showed marked increases with 3,5-DMAP treatment versus the control and both were prevented by Asc treatment. Lipid peroxidation is a good indicator of intracellular oxidation (Alia et al., 2006; Mateos \& Bravo, 2007). During LP, unstable hydroperoxides break down to smaller and more stable products, particularly to malonyldialdehyde (MDA) and 4-hydroxynonenal (HNE) (Emerit et al., 1991). These end-products can attack several cellular targets, particularly proteins. Thus, carbonyl groups may be introduced into proteins by reactions with MDA or HNE. Besides, direct oxidation of Lys, arginine, proline and threonine residues may yield carbonyl derivatives (Esterbauer et al., 1991; Uchida 

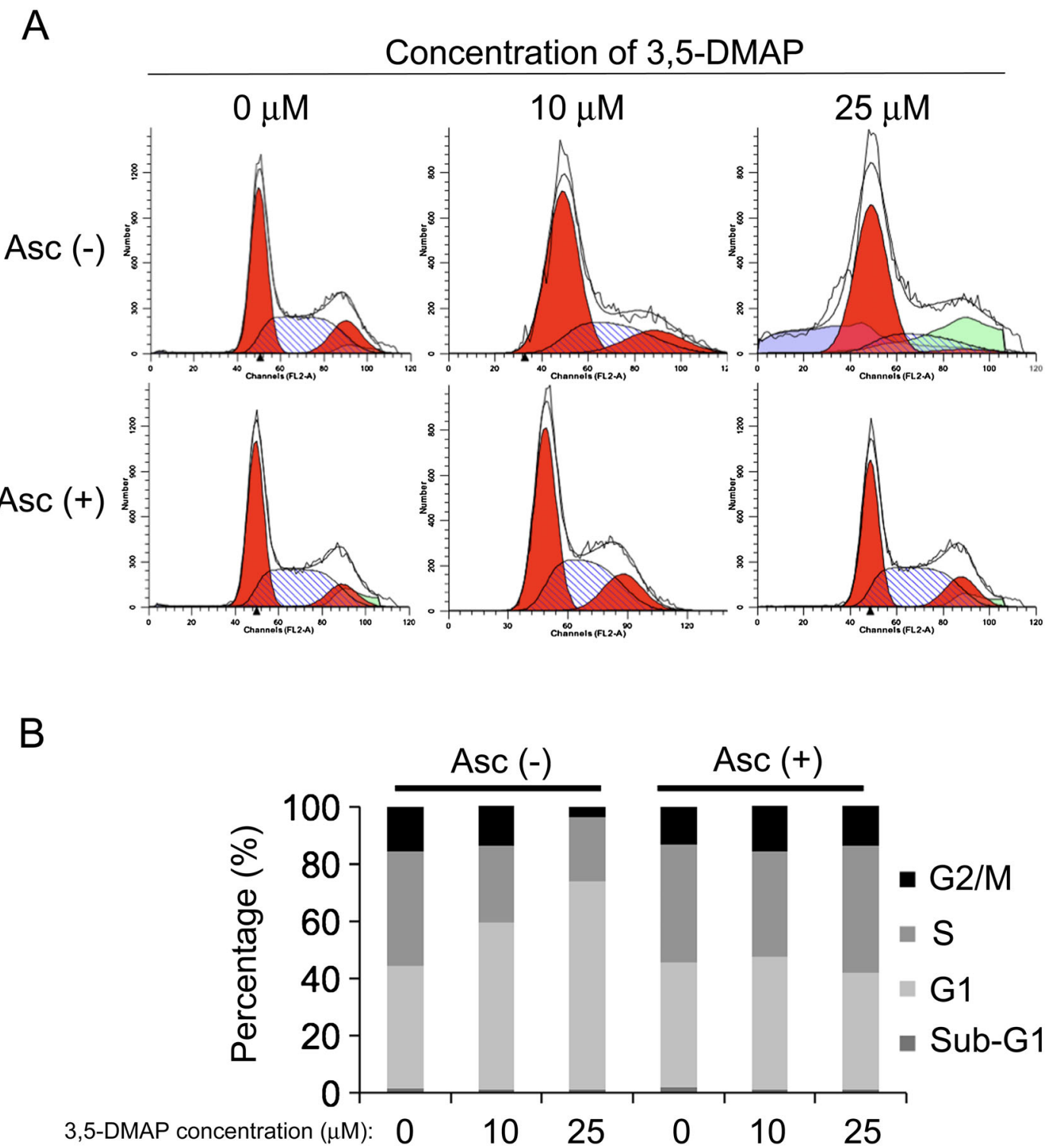

Figure 5. Cell-cycle arrest in 3,5-DMAP \pm Asc-treated cells. Flow cytometric analysis of the cell cycle. (A) Cell cycle analysis. AA8 cells were pretreated with 10 and $25 \mu \mathrm{M}$ 3,5-DMAP. The values represent the number of cells in the various phases of the cell cycle as a likely percentage of total cells. (B) Quantification analysis of G0/G1, S and G2/M cell cycle from flow cytometry. Cell cycle percentages were derived from flow cytometric analysis of AA8 cells treated with 3,5-DMAP $(25 \mu \mathrm{M})$ showed an approximate $30 \%$ increase in $\mathrm{G} 1$ cell cycle arrest and $18 \%$ and $12 \%$ decrease in $\mathrm{S}$ phase and G2/M arrests, respectively. Asc treatment in the presence of 3,5-DMAP only had a slight effect (G2/M arrest) on cell-cycle arrest.

et al., 1993; Winkler et al., 1984). Changes in the cell redox status can also change thiol groups in proteins and alter the activation of cell signaling proteins (Trachootham et al., 2008). Besides, MDA and HNE can interact with DNA, thereby inducing mutagenecity and carcinogenicity (de Zwart et al., 1999).

Although Asc was successful for maintaining a healthy cellular redox state when 3,5-DMAP was applied, it did not provide any protection against higher doses of 3,5-DMAP when Aprt mutation frequency is of concern. This phenomenon might be as a result the high cytotoxic property of 3,5-DMAP at $50 \mu \mathrm{M}$, as at this concentration 3,5-DMAP might lead to high cytotoxicity which might mask its mutagenic potential. We have previously argued that 3,5-DMAP induced gpt mutagenesis in AS52 cells and that DNA damage occured primarily through reaction with ROS rather than formation of covalent adducts (Chao et al., 2012).

It is well know that Lys acetylation of histone $\mathrm{H} 3$ and $\mathrm{H} 4$ may play a vital role in the regulation of many cellular processes such as cell cycle regulation, cell proliferation and apoptosis (Chen et al., 2013; Takebe et al., 2014). An imbalance in the equilibrium of histone acetylation has been connected to tumorigenesis and cancer progression, or cell-cycle arrest. Transimination targets histone proteins as these proteins are Lys rich. Sequentially, 3,5-DMQI can be embedded in the nucleosome and then can produce ROS in maximal proximity to the genome (Ye et al., 2012). As shown in Fig. 3, 3,5-DMAP is found to anchor onto these Lys amino acids of $\mathrm{H} 3$ and $\mathrm{H} 4$, where acetyl groups should locate. In contrast, it is well known that HATs play a critical role in transcriptional activation of gene expression through modifying $\mathrm{N}$-terminal Lys residues of histones (Kuo \& Allis, 1998). Similarly, HDACs also have a fundamental role in transcriptional regulation of gene expression through the hydrolytic removal of acetyl groups from histone Lys residues (Johnson, 2000). HDACs are tightly involved in cell cycle regulation and cell proliferation. Abnormal HAT and HDAC activity displays significant effects on apoptosis, cell-cycle arrest and 
carcinogenicity (Huang et al., 2011; Marks et al., 2000; Reuter et al., 2011). Exposure to 3,5-DMAP is shown to increase the $\mathrm{H} 3$ and $\mathrm{H} 4$ acetylations with a decrease in HAT activity and an increase HDAC activity in AA8 cells. The increase in HDAC activity and the decrease in HAT activity might be in response to $\mathrm{H} 3$ and $\mathrm{H} 4$ hyperacetylation. The $\mathrm{H} 3$ and $\mathrm{H} 4$ hyperacetylation and the acetylation caused by 3,5-DMAP on certain Lys side chains is definitively involved in epigenetic change. This non-biological modification through hydroxyphenylation may inhibit or alter the normal cellular functions. Furthermore, $\mathrm{H} 3$ and $\mathrm{H} 4$ acetylation remains at control levels when Asc was applied with 3,5-DMAP. It might be because of this vitamin's ability to inhibit 3,5-DMAP's redox cycling. Consequently, the electrophilic intermediate quinoneimine cannot react with protein thiol groups. Thus, the chance of 3,5DMAP to target and anchor onto the Lys of histone reduces in the presence of Asc. The biological consequences of 3,5-DMQI transimination may be important, particulary as they relate to hydroxyphenylation of the Lys side chains of the histones. As noted above, this reaction embeds a redox active center in the nucleosome where it is positioned for maximum efficacy to induce genetic damage by ROS. As shown in Fig. 4, the exogenous ROS generated from the synthesized Lys bound 3,5-DMAP showed a dose-dependent increase. It confirms the results of our previous study which mentioned that 3,5-DMAP could be embedded in the nucleosome, could be converted to $3,5-\mathrm{DMQI}$ and later could produce ROS in maximal proximity to the genome (Ye et al., 2012).

In several previous studies, it was indicated that acetylation of histone $\mathrm{H} 3$ and $\mathrm{H} 4$ may play a vital role in the regulation of many cellular processes such as cell-cycle regulation, cell proliferation and apoptosis (Chen et al., 2013; Huang et al., 2011; Myzak et al., 2006). Moreover, the results presented in Figs 3 and 4 show that 3,5-DMAP might have a potential to induce alterations in cell cycle phases and epigenome. We further used flow cytometry to apply the proportion of cell cycle in response to 3,5-DMAP \pm Asc herein. Figure 5 shows that 3,5-DMAP causes cell-cycle arrest at the G1 phase, and shortens the $\mathrm{G} 2$ phase in a dose-dependent manner. These findings confirm the previous results indicating that 3,5-DMAP located onto the Lys of histones, continuously caused ROS generation, and then damaged DNA and affected both DNA synthesis and cell division (Fig. 3). However, when Asc was applied with 3,5-DMAP, Asc mitigated the effects of 3,5-DMAP and raised the $S$ and $\mathrm{G} 2 / \mathrm{M}$ ratio from $23 \%$ to $44 \%$ and $3.7 \%$ to $15 \%$ $(P<0.01, n=3)$, respectively.

In conclusion, 3,5-DMAP causes both cytotoxicity and ROS production in AA8 cells. The cellular stress caused by this particular alkylaniline leads to both genetic (Aprt mutagenesis) and epigenetic changes. Therefore, we can suggest that 3,5-DMAP induces an imbalance in cellular antioxidant/oxidant status causing DNA damage and epigenetic alterations, which can further trigger molecular events, that might eventually cause cancer. Asc is found to be protective against oxidative stress and is able to reduce both genetic and epigenetic events induced by 3,5-DMAP exposure herein.

\section{Acknowledgments}

This work was supported by the National Institute of Environmental Health Sciences grant P01-ES006052 and National Institute of Environmental Health Sciences Center Grant ES02109.

\section{Conflict of Interest}

The Authors did not report any conflict of interest.

\section{References}

Alia M, Ramos S, Mateos R, Granado-Serrano AB, Bravo L, Goya L. 2006. Quercetin protects human hepatoma HepG2 against oxidative stress induced by tert-butyl hydroperoxide. Toxicol. Appl. Pharmacol. 212: $110-118$.

Ames PR, Alves J, Murat I, Isenberg DA, Nourooz-Zadeh J. 1999. Oxidative stress in systemic lupus erythematosus and allied conditions with vascular involvement. Rheumatology 38: 529-534.

Arner ES. 1999. Superoxide production by dinitrophenyl-derivatized thioredoxin reductase--a model for the mechanism and correlation to immunostimulation by dinitrohalobenzenes. Biofactors 10: 219-226.

Arner ES, Zhong L, Holmgren A. 1999. Preparation and assay of mammalian thioredoxin and thioredoxin reductase. Methods Enzymol. 300: 226-239.

Baliga MS, Wang H, Zhuo P, Schwartz JL, Diamond AM. 2007. Selenium and GPx-1 overexpression protect mammalian cells against UVinduced DNA damage. Biol. Trace Elem. Res. 115: 227-242.

Barnham KJ, Masters CL, Bush Al. 2004. Neurodegenerative diseases and oxidative stress. Nat. Rev. Drug Discov. 3: 205-214.

Bendich A, Langseth L. 1995. The health effects of vitamin C supplementation: a review. J. Am. Coll. Nutr. 14: 124-136.

Blokhina O, Virolainen E, Fagerstedt KV. 2003. Antioxidants, oxidative damage and oxygen deprivation stress: a review. Ann. Botany 91 Spec No: 179-194.

Bryant MS, Vineis P, Skipper PL, Tannenbaum SR. 1988. Hemoglobin adducts of aromatic amines: associations with smoking status and type of tobacco. Proc. Natl. Acad. Sci. U. S. A. 85: 9788-9791.

Bryant MS, Simmons HF, Harrell RE, Hinson JA. 1994. 2,6Dimethylaniline--hemoglobin adducts from lidocaine in humans. Carcinogenesis 15: 2287-2290.

Castelao JE, Yuan JM, Skipper PL, Tannenbaum SR, Gago-Dominguez M, Crowder JS, Ross RK, Yu MC. 2001. Gender- and smoking-related bladder cancer risk. J. Natl. Cancer Inst. 93: 538-545.

Chao MW, Kim MY, Ye W, Ge J, Trudel LJ, Belanger CL, Skipper PL, Engelward BP, Tannenbaum SR, Wogan GN. 2012. Genotoxicity of 2,6- and 3,5-dimethylaniline in cultured mammalian cells: the role of reactive oxygen species. Toxicol. Sci. 130: 48-59.

Chao MW, Erkekoglu P, Tseng CY, Ye W, Trudel L, Skipper PL, Tannenbaum SR, Wogan GN. 2014. Intracellular Generation of ROS by 3,5-Dimethylaminophenol: Persistence, Cellular Response, and Impact of Molecular Toxicity. DOI:10.1093/toxsci/kfu127.

Chen D, Fang L, Li H, Tang MS, Jin C. 2013. Cigarette smoke component acrolein modulates chromatin assembly by inhibiting histone acetylation. J. Biol. Chem. 288: 21678-21687.

Choe E, Min DB. 2006. Chemistry and reactions of reactive oxygen species in foods. Crit. Rev. Food Sci. Nutr. 46: 1-22.

Crott JW, Fenech M. 1999. Effect of vitamin C supplementation on chromosome damage, apoptosis and necrosis ex vivo. Carcinogenesis 20: 1035-1041.

Dickinson DA, Forman HJ. 2002. Cellular glutathione and thiols metabolism. Biochem. Pharmacol. 64: 1019-1026.

Emerit I, Khan SH, Esterbauer H. 1991. Hydroxynonenal, a component of clastogenic factors? Free Radic. Biol. Med. 10: 371-377.

Erkekoglu P, Baydar T. 2010. Evaluation of the protective effect of ascorbic acid on nitrite- and nitrosamine-induced cytotoxicity and genotoxicity in human hepatoma line. Toxicol. Mech. Methods 20: $45-52$.

Erkekoglu P, Chao MW, Ye W, Ge J, Trudel L, Skipper PL, Giray B, Engelward BP, Wogan GN, Tannenbaum SR. 2014. Cytoplasmic and nuclear toxicity of 3,5-dimethylaminophenol and potential protection by selenocompounds. Food and Chem. Toxicol. 72: 98-110.

Esterbauer H, Schaur RJ, Zollner H. 1991. Chemistry and biochemistry of 4-hydroxynonenal, malonaldehyde and related aldehydes. Free Radic. Biol. Med. 11: 81-128.

Evans P, Halliwell B. 2001. Micronutrients: oxidant/antioxidant status. Br. J. Nutr. 85(Suppl 2): S67-74.

Flohe L, Gunzler WA. 1984. Assays of glutathione peroxidase. Methods Enzymol. 105: 114-121. 
Gago-Dominguez M, Castelao JE, Yuan JM, Yu MC, Ross RK. 2001. Use of permanent hair dyes and bladder-cancer risk. Int. J. Cancer 91: 575-579.

Gago-Dominguez M, Yuan JM, Sun CL, Lee HP, Yu MC. 2003. Opposing effects of dietary n-3 and n- 6 fatty acids on mammary carcinogenesis: The Singapore Chinese Health Study. Br. J. Cancer 89: 1686-1692.

Gan J, Skipper PL, Gago-Dominguez M, Arakawa K, Ross RK, Yu MC, Tannenbaum SR. 2004. Alkylaniline-hemoglobin adducts and risk of non-smoking-related bladder cancer. J. Natl. Cancer Inst. 96: $1425-1431$.

Halliwell B. 2011. Free radicals and antioxidants - quo vadis? Trends Pharmacol. Sci. 32: 125-130.

Halliwell B, Cross CE. 1994. Oxygen-derived species: their relation to human disease and environmental stress. Environ. Health Perspect. 102(Suppl 10): 5-12.

Headley JV, Maxwell DB, Swyngedouw C, Purdy JR. 1996. Determination of combined residues of metalaxyl and 2,6-dimethylaniline metabolites in urine by gas chromatography/mass spectrometry. J. AOAC Int. 79: 117-123.

Hill BA, Davison KL, Dulik DM, Monks TJ, Lau SS. 1994. Metabolism of 2-(glutathion-S-yl)hydroquinone and 2,3,5- (triglutathion-S-yl)hydroquinone in the in situ perfused rat kidney: relationship to nephrotoxicity. Toxicol. Appl. Pharmacol. 129: 121-132.

Huang J, Plass C, Gerhauser C. 2011. Cancer chemoprevention by targeting the epigenome. Curr. Drug Targets 12: 1925-1956.

IARC. 1993. 2,6-Dimethylaniline (2,6-xylidine). IARC Monogr. Eval. Carcinog. Risks Hum. 57: 323-335.

Johnson CA. 2000. Chromatin modification and disease. J. Med. Genet. 37: 905-915.

Kern JC, Kehrer JP. 2005. Free radicals and apoptosis: relationships with glutathione, thioredoxin, and the BCL family of proteins. Front. Biosci. 10: $1727-1738$.

Krieg RC, Dong Y, Schwamborn K, Knuechel R. 2005. Protein quantification and its tolerance for different interfering reagents using the BCA-method with regard to 2D SDS PAGE. J. Biochem. Biophys. Methods 65: 13-19.

Kuo MH, Allis CD. 1998. Roles of histone acetyltransferases and deacetylases in gene regulation. Bioessays 20: 615-626.

Marks PA, Richon VM, Rifkind RA. 2000. Histone deacetylase inhibitors: inducers of differentiation or apoptosis of transformed cells. J. Natl. Cancer Inst. 92: 1210-1216.

Martindale JL, Holbrook NJ. 2002. Cellular response to oxidative stress: signaling for suicide and survival. J. Cell. Physiol. 192: 1-15.

Mateos R, Bravo L. 2007. Chromatographic and electrophoretic methods for the analysis of biomarkers of oxidative damage to macromolecules (DNA, lipids, and proteins). J. Sep. Sci. 30: 175-191.

Myzak MC, Dashwood WM, Orner GA, Ho E, Dashwood RH. 2006. Sulforaphane inhibits histone deacetylase in vivo and suppresses tumorigenesis in Apc-minus mice. FASEB J. 20: 506-508.
Niki E, Noguchi N, Tsuchihashi H, Gotoh N. 1995. Interaction among vitamin C, vitamin E, and beta-carotene. Am. J. Clin. Nutr. 62: 1322S-1326S.

Peters U, Takata Y. 2008. Selenium and the prevention of prostate and colorectal cancer. Mol. Nutr. Food Res. 52: 1261-1272.

Reszka E 2012. Selenoproteins in bladder cancer. Clin. Chim. Acta 413: 847-854.

Reuter S, Gupta SC, Park B, Goel A, Aggarwal BB. 2011. Epigenetic changes induced by curcumin and other natural compounds. Genes Nutr 6: 93-108.

Richard MJ, Portal B, Meo J, Coudray C, Hadjian A, Favier A. 1992. Malondialdehyde kit evaluated for determining plasma and lipoprotein fractions that react with thiobarbituric acid. Clin. Chem. 38: 704-709.

Ronzoni S, Faretta M, Ballarini M, Pelicci P, Minucci S. 2005. New method to detect histone acetylation levels by flow cytometry. Cytometry 66: 52-61.

Skipper PL, Kim MY, Sun HL, Wogan GN, Tannenbaum SR. 2010. Monocyclic aromatic amines as potential human carcinogens: old is new again. Carcinogenesis 31: 50-58.

Takebe M, Oishi H, Taguchi K, Aoki Y, Takashina M, Tomita K, Yokoo H, Takano Y, Yamazaki M, Hattori Y. 2014. Inhibition of histone deacetylases protects septic mice from lung and splenic apoptosis. J. Surg. Res. 187: 559-570.

Trachootham D, Lu W, Ogasawara MA, Nilsa RD, Huang P. 2008. Redox regulation of cell survival. Antioxid. Redox Signal. 10: 1343-1374.

Uchida K, Szweda LI, Chae HZ, Stadtman ER. 1993. Immunochemical detection of 4-hydroxynonenal protein adducts in oxidized hepatocytes. Proc. Natl. Acad. Sci. U. S. A. 90: 8742-8746.

Vallejo F, Tomás Barberán F, García-Viguera C. 2002. Glucosinolates and vitamin $\mathrm{C}$ content in edible parts of broccoli florets after domestic. Eur Food Res. Technol. 215: 310-316.

Winkler P, Lindner W, Esterbauer H, Schauenstein E, Schaur RJ, Khoschsorur GA. 1984. Detection of 4-hydroxynonenal as a product of lipid peroxidation in native Ehrlich ascites tumor cells. Biochim. Biophys. Acta 796: 232-237.

Wu RW, Panteleakos FN, Felton JS. 2003. Development and characterization of $\mathrm{CHO}$ repair-proficient cell lines for comparative mutagenicity and metabolism of heterocyclic amines from cooked food. Environ. Mol. Mutagen. 41: 7-13.

Wu JT, Han BM, Yu SQ, Wang HP, Xia SJ. 2010. Androgen receptor is a potential therapeutic target for bladder cancer. Urology $\mathbf{7 5 :}$ 820-827.

Ye W, Seneviratne UI, Chao MW, Ravindra KC, Wogan GN, Tannenbaum SR, Skipper PL. 2012. Transimination of quinone imines: a mechanism for embedding exogenous redox activity into the nucleosome. Chem. Res. Toxicol. 25: 2627-2629.

de Zwart LL, Meerman JH, Commandeur JN, Vermeulen NP. 1999. Biomarkers of free radical damage applications in experimental animals and in humans. Free Radic. Biol. Med. 26: 202-226. 